\title{
The Corrosion Process of an API 5L X80 Welded Joint in a System with Different pH and $\mathrm{H}_{2} \mathrm{~S}$ Concentration
}

\author{
M. B. L. Carvalho ${ }^{*}$ (D), I. S. Bott ${ }^{a}$ (D), A. B. Forero $^{b}$, J. A. C. Ponciano ${ }^{c}$ (D) \\ ${ }^{a}$ Pontificia Universidade Católica do Rio de Janeiro, Departamento de Engenharia Química e de \\ Materiais, Rua Marquês de São Vicente, 225, Gávea, 22453-900, Rio de Janeiro, RJ, Brasil. \\ ${ }^{b}$ Compañia Massy Energy Colombia, Cra. 45 $5^{\circ}$ 93-64, Bogotá, Colombia. \\ ${ }^{c}$ Universidade Federal do Rio de Janeiro, Centro de Tecnologia, Departamento de Engenharia \\ Metalúrgica e de Materiais, Laboratório de Corrosão (LabCorr), Avenida Horácio Macedo, 2030, \\ Bloco F, Cidade Universitária, 21941-598, Rio de Janeiro, RJ, Brazil.
}

Received: September 03, 2021; Revised: December 16, 2021; Accepted: December 22, 2021

\begin{abstract}
The corrosion evaluation of steels in the oil and gas industry environments is a crucial issue because corrosion can cause economic and human losses. It is well known that $\mathrm{H}_{2} \mathrm{~S}$ can be originated from different processes in the oil and gas industry, accelerating the corrosion process. The objective of this work was to evaluate the $\mathrm{H}_{2} \mathrm{~S}$ corrosion resistance of an API 5L X80 steel and its welded joint obtained by submerged arc welding process (SAW). All tests were performed in an aerated $5 \% \mathrm{wt} \mathrm{NaCl}$ and thiosulphate aqueous solution. The $\mathrm{H}_{2} \mathrm{~S}$ concentration, $\mathrm{pH}$, weight loss, electrochemical tests, and microstructure were considered. The results obtained showed an increase of the corrosion rate values, with decreasing $\mathrm{pH}$ and increasing concentration of $\mathrm{H} 2 \mathrm{~S}$ generated by the thiosulphate. For the lowest $\mathrm{H}_{2} \mathrm{~S}$ concentrations, the corrosion process was inhibited, due to the formation of a partially protective film on the samples' surfaces. The heat affected zone (HAZ) showed severe localized corrosion attack which was attributed to the microstructural characteristics of this region.
\end{abstract}

Keywords: Corrosion, $\mathrm{H}_{2} \mathrm{~S}$, API $5 \mathrm{~L}$ X80, Welded joint, Electrochemical tests, Weight loss tests.

\section{Introduction}

The deterioration of a buried metal that has been submerged or exposed to industrial environments represents a real problem for the economy and the environment. It is well known that $\mathrm{H}_{2} \mathrm{~S}$ originating from different processes in the oil and gas industry can accelerate anodic and cathodic reactions of the

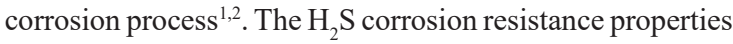
of steels depend not only upon the steel cleanliness, but also on its microstructure ${ }^{3-11}$. The welding procedures adopted during the production of the tubes and for construction of the pipelines can modify its microstructure and, consequently, the mechanical and corrosion properties of the base metal in the heat affected zone (HAZ). These changes can increase the corrosion attack in these specific zones ${ }^{11-17}$. Corrosion rates of low alloy steels in $\mathrm{H}_{2} \mathrm{~S}$ containing environment tend to increase with increasing $\mathrm{H}_{2} \mathrm{~S}$ concentration and decreasing $\mathrm{pH}$ of the aqueous solution ${ }^{18}$.

In the present work, weight loss tests and electrochemical tests (linear polarization resistance (LPR), Tafel curves (TC) and electrochemical impedance spectroscopy (EIS)) were used to calculate the corrosion rate, in order to investigate the effect of $\mathrm{H}_{2} \mathrm{~S}$ concentration and $\mathrm{pH}$ of system $\mathrm{pH}$ on the corrosion process of an API 5L X80 steel and its SAW welded joint. The results obtained showed that the corrosion rate accomplished for both base metal (BM)

*e-mail: nickcarvalho9@gmail.com and the welded joint (WJ) increased with the decreasing $\mathrm{pH}$, regardless of the $\mathrm{H}_{2} \mathrm{~S}$ concentration generated by the thiosulphate.

In this work, the corrosion process was inhibited for the lowest $\mathrm{H}_{2} \mathrm{~S}$ concentration, causing a significant decrease in the corrosion rate. This effect could be a result of a partially protective film formed on the samples' surface for the solution with low $\mathrm{H}_{2} \mathrm{~S}$ concentration. However, a more severe attack in the HAZ was present, indicating an influence of the microstructure on the corrosion attack mechanism.

\section{Experimental Procedure}

\subsection{Materials}

The material of this study was an API 5LX80 steel. Samples of base metal and welded joint (weld metal and heat affected zone (HAZ)) were taken from a tube welded longitudinally by submerged arc welding (SAW) process, as shown in Figure 1.

The average values of the chemical composition (Table 1), sampled from two different points of the BM and the WJ, were obtained using the optical emission spectroscopy technique according to ASTM E 415-2008.

Microstructural analyses, using Optical Microscopy Zeiss Axioskop (OM), were performed, and the samples 


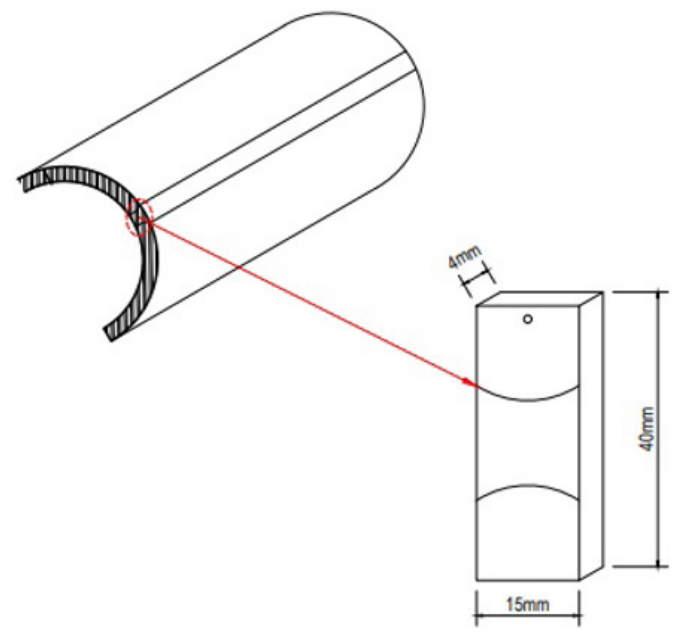

Figure 1. Specimen dimensions in $\mathrm{mm}$.

Table 1. Chemical Compositions of the base metal and weld metal in $w \mathrm{t} \%$.

\begin{tabular}{cccc}
\hline Element & $\begin{array}{c}\text { Base Metal } \\
(\%) \text { wt content }\end{array}$ & $\begin{array}{c}\text { Weld Metal } \\
(\%) \text { wt content }\end{array}$ & $\begin{array}{c}\text { API 5L Max } \\
(\%) \text { wt content }\end{array}$ \\
\hline $\mathrm{C}$ & 0,058 & 0,056 & 0,22 \\
\hline $\mathrm{Si}$ & 0,203 & 0,273 & - \\
\hline $\mathrm{Mn}$ & 1,71 & 1,59 & 1,85 \\
\hline $\mathrm{P}$ & 0,023 & 0,027 & 0,025 \\
\hline $\mathrm{S}$ & 0,0031 & 0,0062 & 0,015 \\
\hline $\mathrm{Cr}$ & 0,131 & 0,100 & - \\
\hline $\mathrm{Ni}$ & 0,020 & 0,023 & - \\
\hline $\mathrm{Mo}$ & 0,192 & 0,178 & - \\
\hline $\mathrm{Al}$ & 0,044 & 0,021 & - \\
\hline $\mathrm{Cu}$ & 0,011 & 0,050 & - \\
\hline $\mathrm{Co}$ & $<0,0015$ & $<0,0015$ & $\mathrm{c}, \mathrm{d}$ \\
\hline $\mathrm{Ti}$ & 0,015 & 0,014 & $\mathrm{c}, \mathrm{d}$ \\
\hline $\mathrm{Nb}$ & 0,064 & 0,037 & - \\
\hline $\mathrm{V}$ & 0,023 & 0,017 & - \\
\hline $\mathrm{B}$ & 0,0007 & 0,0027 & \\
\hline $\mathrm{Ca}$ & 0,0032 & 0,0016 & $\mathrm{~B}$ \\
\hline $\mathrm{Fe}$ & $\mathrm{Balance}$ & $\mathrm{Balance}$ & $\mathrm{c}$ \\
\hline
\end{tabular}

c Niobium, Vanadium, Titanium, or combinations thereof may be used at the discretion of the manufacturer; $d$ Sum of the Niobium, Vanadium, and Titanium contents not exceed $0,15 \%$ (API $5 \mathrm{~L}, 2007$ ).

were prepared using the conventional method of grinding and etching with a $2 \%$ Nital solution for 5 to 10 seconds. Electrolytic double etching technique was also used to adequately reveal the presence of martensite and austenite microconstituent (MA) for Scanning Electron Microscopy JEOL (JSM-6510L) (SEM) analysis, as shown in Figure 2.

\subsection{Weight loss tests}

The effect of $\mathrm{pH}, \mathrm{H}_{2} \mathrm{~S}$ concentration and microstructural characteristics on the corrosion rate and corrosion products morphology were studied using the weight loss technique in a $5 \% \mathrm{wt} \mathrm{NaCl}$ brine and different corrosive environments based on a sodium thiosulphate solution, as listed in Table 2.

$\mathrm{H}_{2} \mathrm{~S}$ was indirectly generated by the reaction of the Sodium thiosulfate solutions at the interface electrolyte/metal, at atmospheric pressure and room temperature according to the reactions ${ }^{7}$ :
Table 2. Chemical composition of the solutions used in electrochemical techniques.

\begin{tabular}{|c|c|c|c|}
\hline Solution & $\begin{array}{c}\text { Sodium } \\
\text { Thiosulphate } \\
\left(\mathrm{Na}_{2} \mathrm{~S}_{2} \mathrm{O}_{3}\right)\end{array}$ & $\begin{array}{l}\text { Sodium } \\
\text { Chloride } \\
(\mathrm{NaCl})\end{array}$ & $\mathrm{pH}$ \\
\hline Brine & 0 & \multirow{6}{*}{$5 \% \mathrm{wt}$} & \multirow{3}{*}{5.0} \\
\hline Solution 1 & $10^{-3} \mathrm{~mol} / \mathrm{L}$ & & \\
\hline Solution 2 & $10^{-2} \mathrm{~mol} / \mathrm{L}$ & & \\
\hline Brine & 0 & & \multirow{3}{*}{3.0} \\
\hline Solution 1 & $10^{-3} \mathrm{~mol} / \mathrm{L}$ & & \\
\hline Solution 2 & $10^{-2} \mathrm{~mol} / \mathrm{L}$ & & \\
\hline
\end{tabular}

$\mathrm{S}_{2} \mathrm{O}_{3}{ }^{2-}+\mathrm{H}^{+}+e^{-}=\mathrm{S}+\mathrm{HSO}_{3}{ }^{2-}$
$\mathrm{S}_{2} \mathrm{O}_{3}{ }^{2-}+6 \mathrm{H}^{+}+4 e^{-}=2 \mathrm{~S}+3 \mathrm{H}_{2} \mathrm{O}$

$S+2 H^{+}+2 e^{-}=H S$

$4 \mathrm{~S}+4 \mathrm{H}_{2} \mathrm{~S}=3 \mathrm{H}_{2} \mathrm{~S}+\mathrm{HSO}_{4}{ }^{-}+\mathrm{H}^{+}$

The specimens of $40 \times 15 \times 4 \mathrm{~mm}$ dimension were washed, grounded using a 220 to 600 grit sandpaper and weighed prior to the test. Three samples of each region (base metal and welded joint) were immersed in the solution for 30 days and tested for the same conditions, as described in Table 2.

After the end of the test and removal of the sample from the solution, the corrosion products were detached from the specimen surface and followed by cleaning, drying and re-weighting according to ASTM G1-03(2011) standard $^{19}$. The corrosion rate was an average of the results obtained from three different samples, using the Equation 5, where $\mathrm{K}=\mathrm{a}$ constant $=3.45 \times 10^{6}, \mathrm{~W}=$ mass loss in $\mathrm{g}, \mathrm{A}=$ Area in $\mathrm{cm}^{2}, \mathrm{~T}=$ time in hours and $\mathrm{D}=$ density in $\mathrm{g} / \mathrm{cm}^{3}(7.85)$.

Corrosion Rate $($ mpy $)=\left(\frac{K^{*} W}{A^{*} T^{*} D}\right)$

Visual, optical (OM) and scanning electron microscopy (SEM) analyses of the sample surfaces were performed to determine the type and morphology of the corrosion process.

\subsection{Electrochemical techniques}

Linear Polarization Resistance (LPR) tests, Tafel polarization curves (TP) and Electrochemical Impedance Spectroscopy (EIS) were applied using different corrosive environments (Table 2), in a typical electrochemical cell of three electrodes, using platinum as the counter electrode and a standard silver/silver chloride electrode $(\mathrm{Ag} / \mathrm{AgCl})$ as reference.

In the LPR test, the triplicate specimens were placed in the electrochemical cell to come in contact with test solution. The specimens were kept immersed in the solution for 3 hours, maintaining the system in open circuit to obtain the stabilization of the corrosion potential $\left(\mathrm{E}_{\text {corr }}\right)$. LPR measurements were carried out by polarizing the specimen from +20 to $-20 \mathrm{mV}$ in respect to $\mathrm{E}_{\text {corr }}$, with scanning rate of $0.6 \mathrm{~V} /$ hour, as specified in ASTM G-59-2003 ${ }^{20}$. 
$\mathrm{R}_{\mathrm{p}}=\left[\frac{d(\Delta E)}{d i}\right]_{\Delta E=0}$

Where $\Delta \mathrm{E}=$ the difference $\mathrm{E}-\mathrm{E}_{\text {corr }}$, and $\mathrm{R}_{\mathrm{p}}=$ polarization resistance in $\left(\Omega \cdot \mathrm{cm}^{2}\right)$.

After recording the LPR tests, in order to reach stabilisation, the system was kept at open circuit potential for approximately two hours. Electrochemical impedance spectroscopy (EIS) was carried out at $\mathrm{E}_{\text {corr }}$, using a $10 \mathrm{mV}$ signal amplitude and a frequency range of $100 \mathrm{kHz}$ to $0.01 \mathrm{~Hz}$.

Tafel polarization curve test was applied using a scanning potential of $250 \mathrm{mV}$ above and below the open circuit potential (Ecorr), approximately 24 hours after immersion. The logarithm of current density obtained was plotted as a function of scanning potential (E vs. Log I). From these curves anodic and cathodic Tafel slopes (ba and bc) were obtained.

The corrosion current density was calculated, using the Stern-Geary equation:

$I_{\text {corr }}=\frac{B}{R_{p}}$

$B=\frac{(b a b c)}{2.303(b a+b c)}$

Where $\mathrm{I}_{\text {corr }}=$ corrosion current density in $\mu \mathrm{A} / \mathrm{cm}^{2}$, ba and $\mathrm{bc}$ are given in $\mathrm{mV} /$ decade, $\mathrm{Rp}=$ polarization resistance $\left(\mathrm{k} \Omega . \mathrm{cm}^{2}\right)$.

The corrosion rate was obtained by the following relationship:

$R_{\text {corr }}=\frac{\left(0.13 I_{\text {corr }} P E\right)}{\rho}$

Where $\mathrm{Rcorr}=$ corrosion rate in mpy, $\mathrm{PE}=$ equivalent weight of metal in $\mathrm{g}, \rho=$ density of metal in $\mathrm{g} / \mathrm{cm}^{3}(7,85$ for low alloy steel)

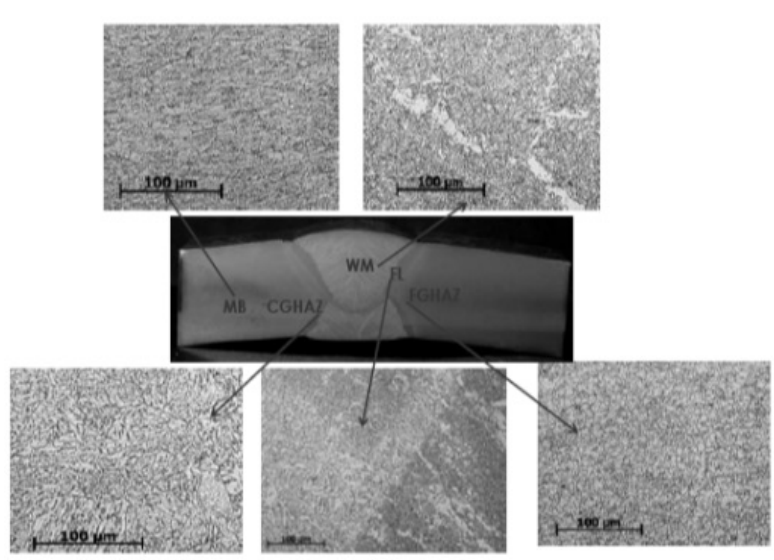

(a)

\section{Results and Discussion}

The Figure 2 shows the base metal exhibited a ferritic matrix with MA microconstituent. The weld metal microstructure was mainly acicular ferrite and grain boundary ferrite and the heat affected zone (HAZ), regardless of the region, usually exhibited ferrite bainitic microstructure with decomposed MA microconstituent. Some regions of the fine grain HAZ display polygonal and almost polygonal ferrite.

The average corrosion rates (Figure 3 ) were obtained from weight loss tests of both regions (base metal and welded joint) in different $\mathrm{H}_{2} \mathrm{~S}$ containing solutions. An increase of the corrosion rates with the decreasing $\mathrm{pH}$ of the solution is shown, this effect being more significant for solution 2. For most steels in $\mathrm{H}_{2} \mathrm{~S}$-containing environments, the corrosion rates tend to increase with decreasing $\mathrm{pH}$ of the aqueous solution $^{21}$. The stable form of $\mathrm{H}_{2} \mathrm{~S}$ depends upon the solution acidity $(\mathrm{pH})$, therefore, $\mathrm{H}_{2} \mathrm{~S}$ is stable as a dissolved species in aqueous solutions only at low $\mathrm{pH}$ levels $(\mathrm{pH} \leq 6)$; whereas at higher $\mathrm{pH}$ levels (between 7 and 11) the predominant form is $\mathrm{HS}^{-}$, and for alkaline $\mathrm{pH}$ values the stable form is $\mathrm{S}^{2-}$.

ASTM D 2688-1122 specifies that uniform corrosion rates smaller than $0.13 \mathrm{~mm} / \mathrm{y}$ are considered low and are a general indication of adequate service life for metals tested and exposed to pipeline systems. As can be seen in Figure 3, the values of corrosion rate obtained for both base metal and the welded joint, in brine and in solution 2 , with $\mathrm{pH}=5.0$ and 3.0, respectively, indicate a severe degradation.

All the values obtained for the specimens tested in Solution 1 are below the limit specified in the standard ASTM D 2688-11. These results are not expected since this system contains $\mathrm{H}_{2} \mathrm{~S}$ generated by the reaction of sodium thiosulphate with the metal surface. However, corrosion rates higher than those obtained in brine would be expected.

The influence of hydrogen sulphide on the steel corrosion, in the vast majority of the cases, showed that the increase in the $\mathrm{H}_{2} \mathrm{~S}$ concentration increases the corrosion rate $\mathrm{e}^{1,21,23-25}$, due to the fact the both processes anodic dissolution and hydrogen evolution are accelerated. However, under certain special operating conditions where $\mathrm{H}_{2} \mathrm{~S}$ concentrations are low $(<0.04 \mathrm{mmol} / 1,<15 \mathrm{ppm}$ or $<0.05 \mathrm{psi})$, $\mathrm{pH}$ values
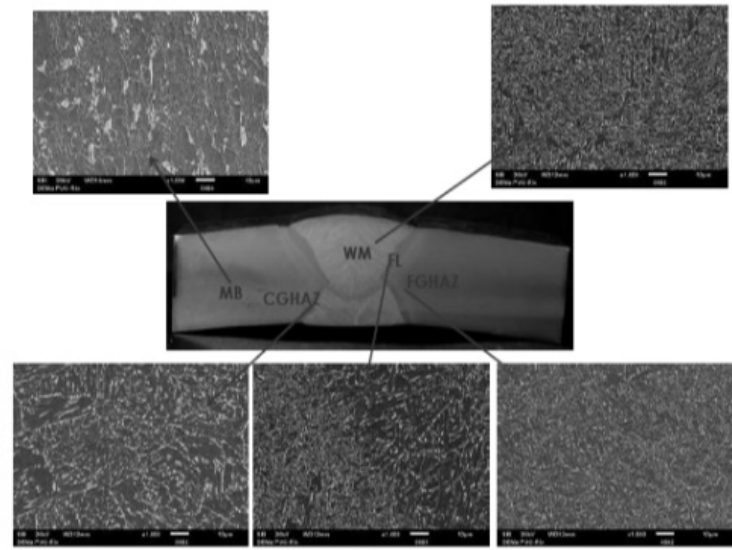

(b)

Figure 2. Microstructural Characterization of welded joint. (a) OM (b) SEM. 


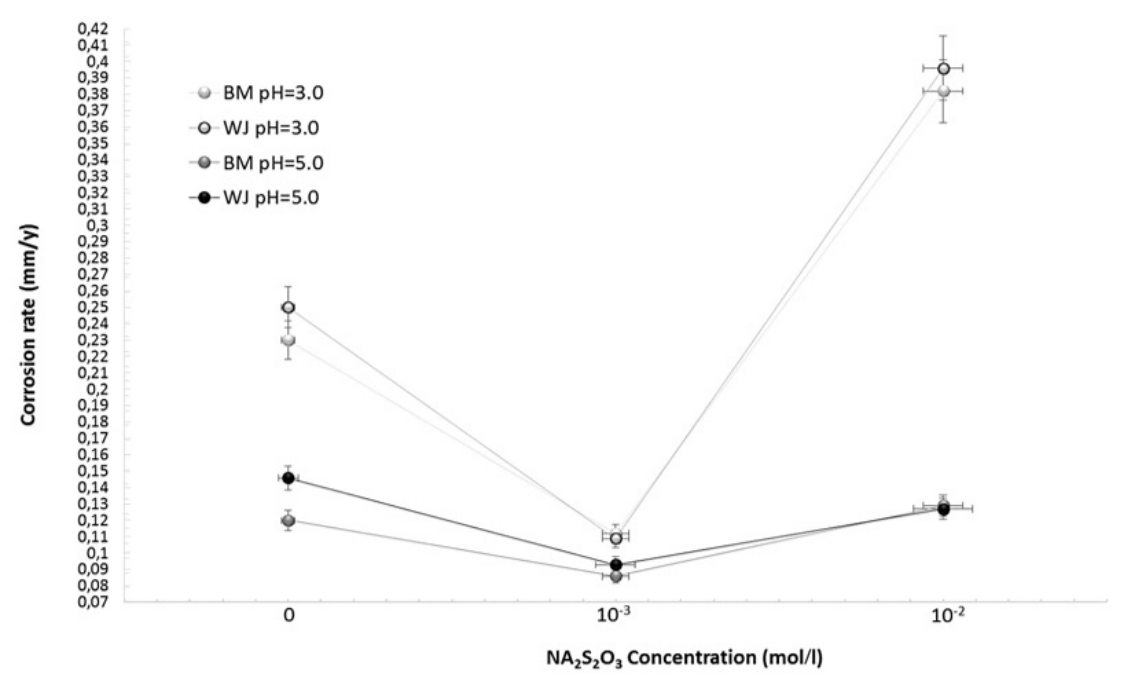

Figure 3. Average corrosion rates obtained by loss weight tests from different solutions.

between 3-5, and immersion times are exceeding two hours, the corrosion process can be inhibited, causing a significant decrease in the corrosion rate ${ }^{1-23}$, as shown by the results obtained for the solution 1 in this study.

In general, iron corrosion in $\mathrm{H}_{2} \mathrm{~S}$-containing solutions leads to the formation of a FexSy film, where the type of sulphide depends on the $\mathrm{H}_{2} \mathrm{~S}$ concentration in the solution. Considering the $\mathrm{H}_{2} \mathrm{~S}$ concentration of the solutions in this work, the corrosion rate was lower for the solution 1 and higher for solution 2. This effect is thought to be caused by the formation of a partially protective film on the samples in solutions with low $\mathrm{H}_{2} \mathrm{~S}$ concentration ${ }^{25}$. Corrosion product layers were formed for all conditions tested, however, apparently, for solution $1(\mathrm{pH}=3.0)$, the layer formed was compact and the metal surface was isolated, thus avoiding the corrosion attack. Figure 4 shows the surface appearance of the specimens that were tested for weight loss before the removal of corrosion products.

Gravimetric analysis associated with quantitative information allows the identification of the type of corrosion that occurs within the system. After the end of each test, the specimens were removed from the cell, manually washed, dried and weighed in accordance with ASTM G1-03(2011) standard. Visual analysis of the samples surface was performed before and after washing, and after the removal of corrosion products, in order to identify the form of corrosion in each medium. The most representative visual aspect of the various systems tested is shown in Figure 5.

For brine tests with $\mathrm{pH}=5.0$, the corrosion was uniform along the sample surface. For $\mathrm{pH}=3.0$, the corrosion was both uniform and localised (pitting), showing a higher pit density in the HAZ at coarse and fine grain regions, as shown in Figures 4.

In general, the samples that submerged in solutions 1 and 2 showed uniform and localised corrosion. The most affected region for pitting corrosion was the HAZ; the preferential attack was more intense for solution 2 where sodium thiosulphate concentration is higher, and $\mathrm{pH}=3.0$, indicating that this solution provides more severe environment.
Detailed SEM analysis showed the selective attack, localised pitting and alveolar types of corrosion at the HAZ and base metal (Figures 6-8). The coarse grain zone of the HAZ is the most affected, possibly due to the microstructural transformations present in this region.

The greatest degradation occurred in the ferrite-bainitic microstructure, as corresponding to the elongated ferrite, and within the partially decomposed microconstituent AM, as related to the ferrite and carbide aggregates. The dark areas probably correspond to clusters of ferrite, while the lighter areas correspond to an aggregate of precipitate and carbides. While the dark areas are more attacked and the lighter areas which have an embossed appearance do not appear to be attacked.

In a corrosive medium containing thiosulphate, the interaction of the environment with the metal surface ${ }^{7}$ generates $\mathrm{H}_{2} \mathrm{~S}$ and, as soon as the cathodic and anodic reactions occur, a layer of corrosion products will be formed. Initially, this layer must be constituted of iron sulphate and oxides and can have protective qualities. However, the observed tendency was a porous and brittle layer. Additionally, this layer can be dissolved by the acid dilution. Therefore, the areas where the layer is broken or weakened can become available to react with the medium and produce $\mathrm{H}_{2} \mathrm{~S}$ in the areas adjacent to the metal surface. This sequence of events leads to a localised attack in these areas, as can be observed in Figures 6-8.

In this work, an increase in the corrosion rate was observed for solution $2(\mathrm{pH}=3.0)$, which indicates that the formed film was not protective under these conditions. For solution 1, a decrease in the corrosion rate was observed for the two studied $\mathrm{pH}$ values, which indicates the formation of a film that inhibits the corrosion process of the metal. Thus, the structure and composition of the films were determined using electron dispersive spectroscopy (EDS) and X-ray diffraction analysis (XRD), shown in Figures 9-12.

The formed films have a discontinuous and porous morphology and were formed mainly of oxides, sulfides and chlorides, as you identify in the EDS spectra. For the specimen tested in solution 2 with $\mathrm{pH}=3.0$, visual inspection 


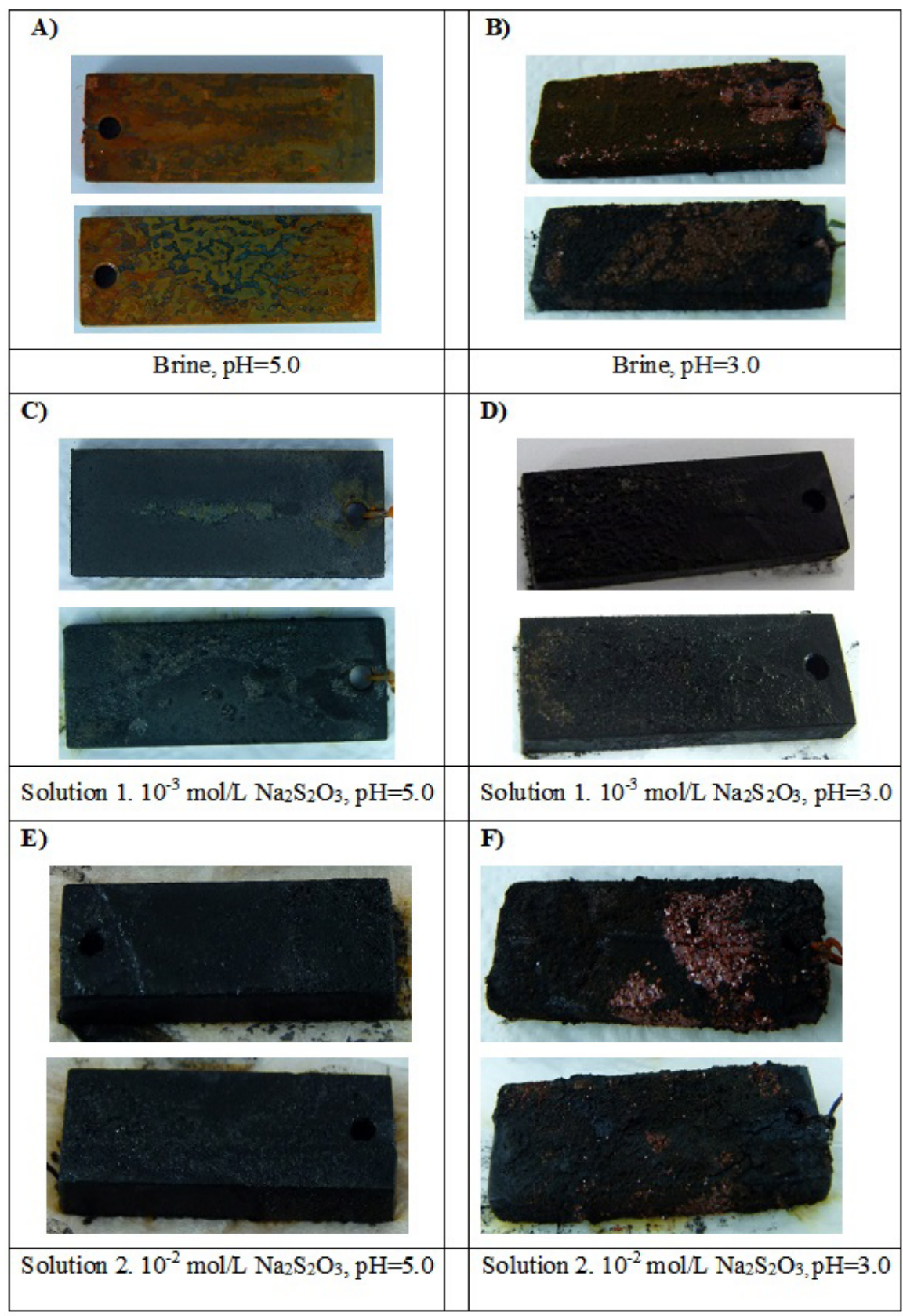

Figure 4. Surface aspect of the weight loss test specimens before removal of corrosion products.

(Figure 4f) suggests the presence of two layers: the first layer grows adjacent to metal surface, an irregular and black layer, showing some degree of porosity. The second layer consists of crystal clusters with a columnar geometry of possibly a more stable iron sulfide, as suggested by EDS spectrum.

Figure 9 shows the EDS spectra from different areas of the layer formed on the surface of the welded joint. The first layer shows the presence of $\mathrm{Fe}, \mathrm{Cl}, \mathrm{Ni}, \mathrm{Na}, \mathrm{Mn}$ and $\mathrm{O}$, whereas the second layer (columnar crystal) is mainly composed of $\mathrm{S}$, $\mathrm{Fe}$, and $\mathrm{Na}$. The spectra obtained from the layers that were apparently formed first indicate the presence of oxygen. It can be said that an oxide layer was initially formed and became a type of meta-stable sulphide (mackinawite), crystals with columnar geometry, which appears to be a type of sulphide enriched in sulphur. This assessment is supported by the XRD spectrum shown in Figure 10.

The corrosion film that formed for the $\mathrm{WJ}$ in solution 1 with $\mathrm{pH}=3.0$ (Figure 10) has different morphologies from that formed in solution 2. This film exhibits an inner layer with a continuous and compact morphology adjacent to the metallic substrate surface and an outer layer with a discontinuous, porous and granular morphology above the inner layer. The EDS spectra (Figure 11) and XRD spectrum (Figure 12) show that the inner layer may be an iron oxide (magnetite or maghemite), and the outer layer may be an iron sulphide (mackinawite). 


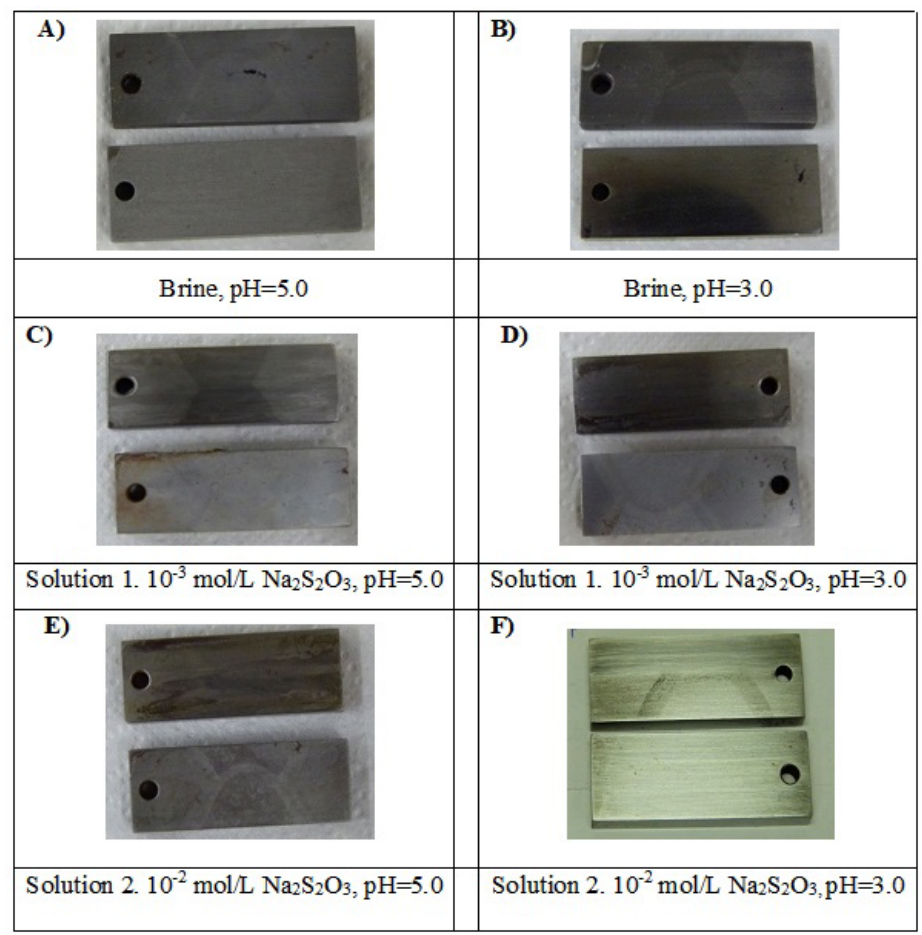

Figure 5. Surface aspect of the weight loss test specimens after removal of corrosion products.

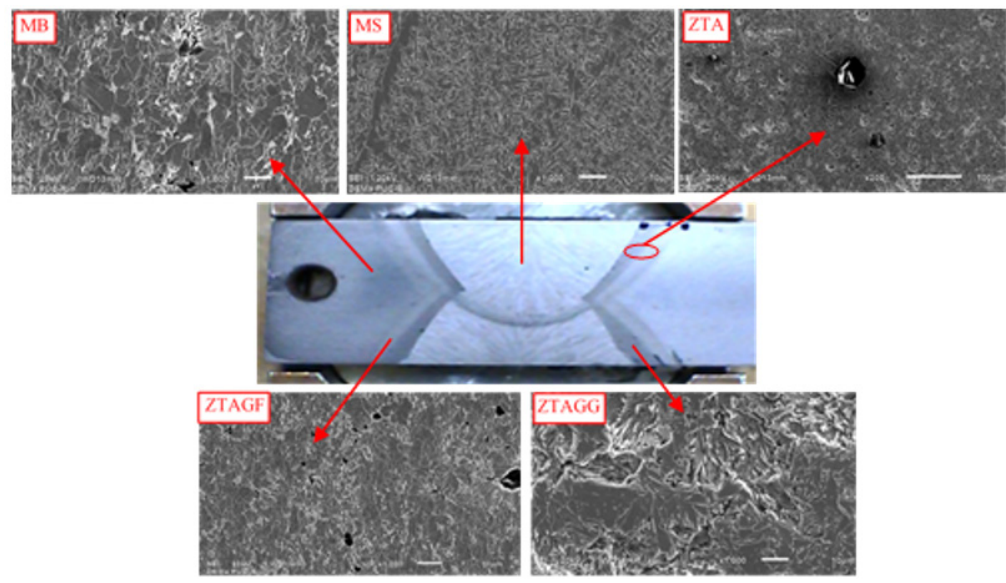

Figure 6. SEM surface characterization of a sample tested in brine $(\mathrm{pH}=3.0)$ after immersion for 30 days.

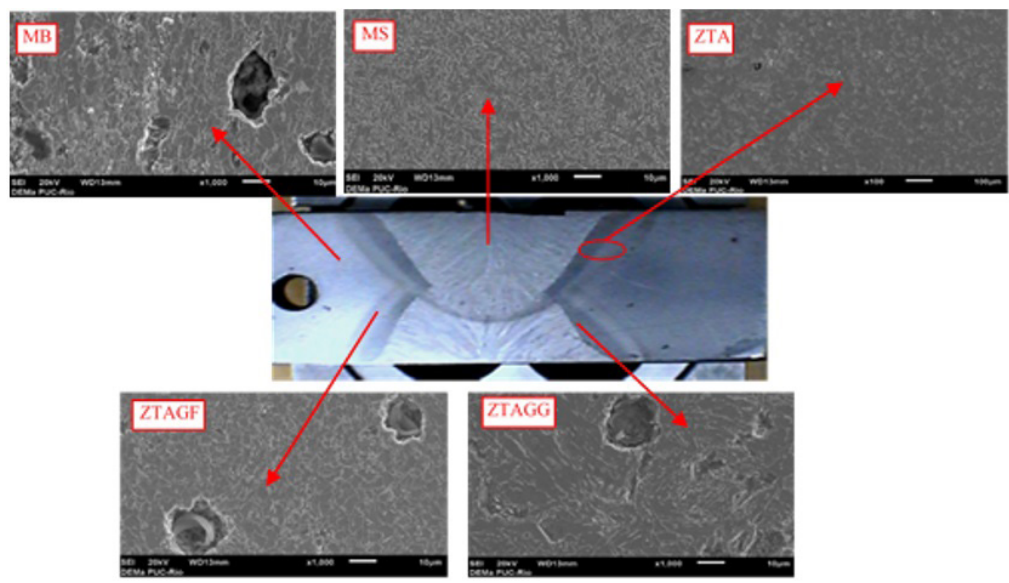

Figure 7. SEM surface characterization of the sample after 30 days immersion at solution $1\left(10^{-3} \mathrm{~mol} / \mathrm{L} \mathrm{Na}_{2} \mathrm{~S}_{2} \mathrm{O}_{3}\right)(\mathrm{pH}=3)$. 


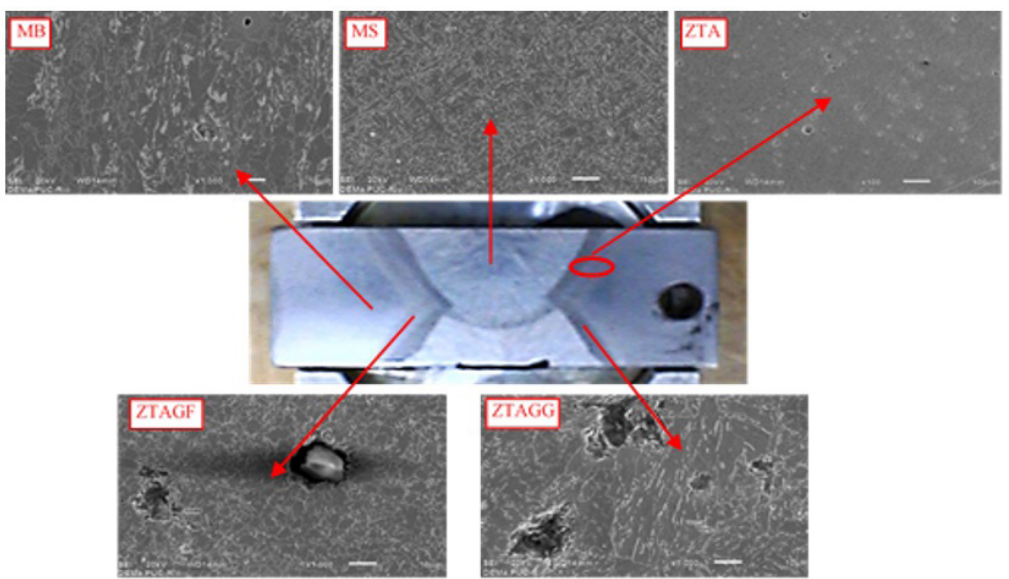

Figure 8. SEM surface characterization of the sample after 30 days immersion in solution $2\left(10^{-2} \mathrm{~mol} / \mathrm{L} \mathrm{Na}_{2} \mathrm{~S}_{2} \mathrm{O}_{3}\right)(\mathrm{pH}=3.0)$.

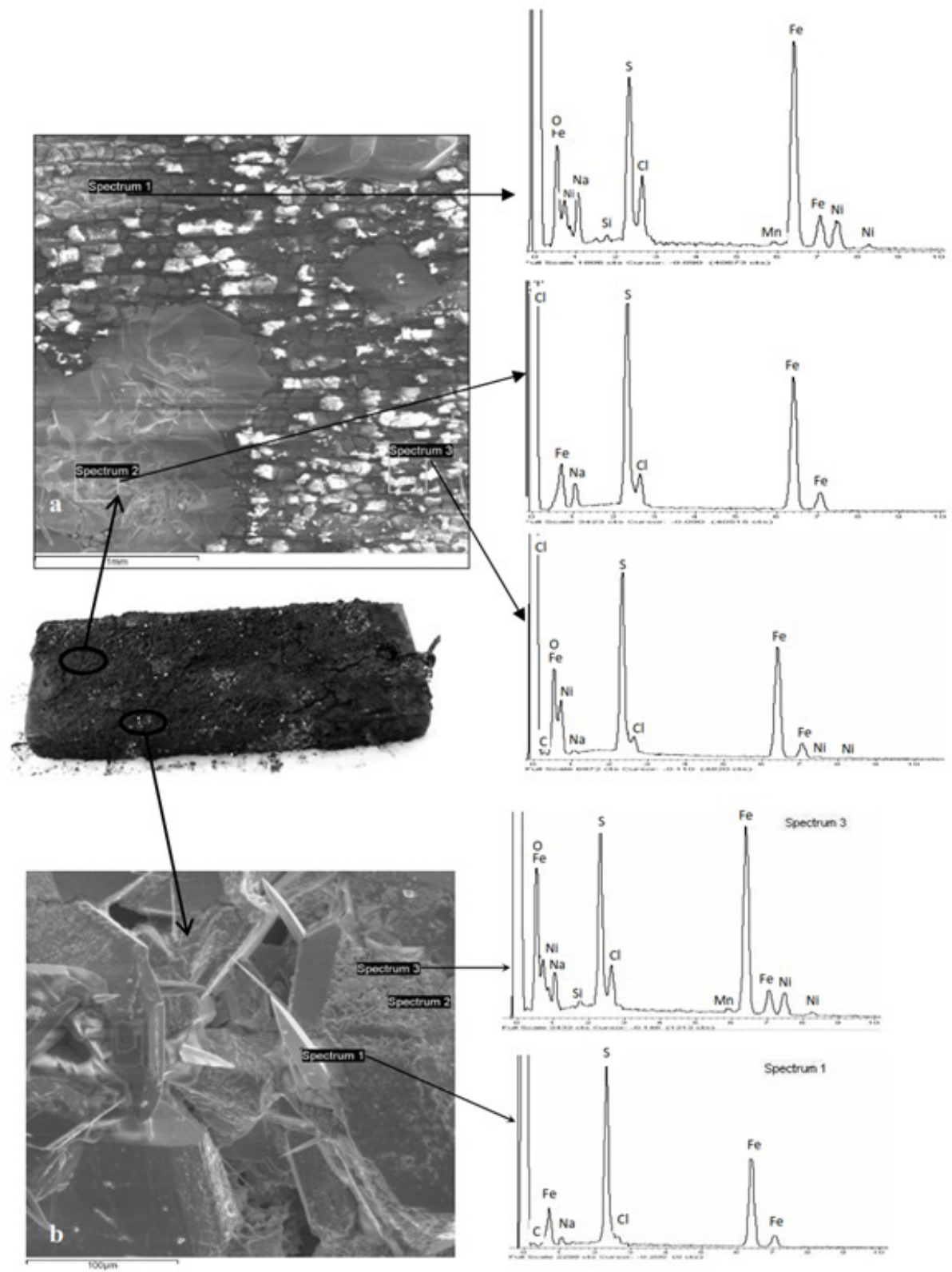

Figure 9. SEM and EDS characterization of the corrosion product film on the surface of the welded joint that was tested in solution 2 with $\mathrm{pH}=3$.0. 


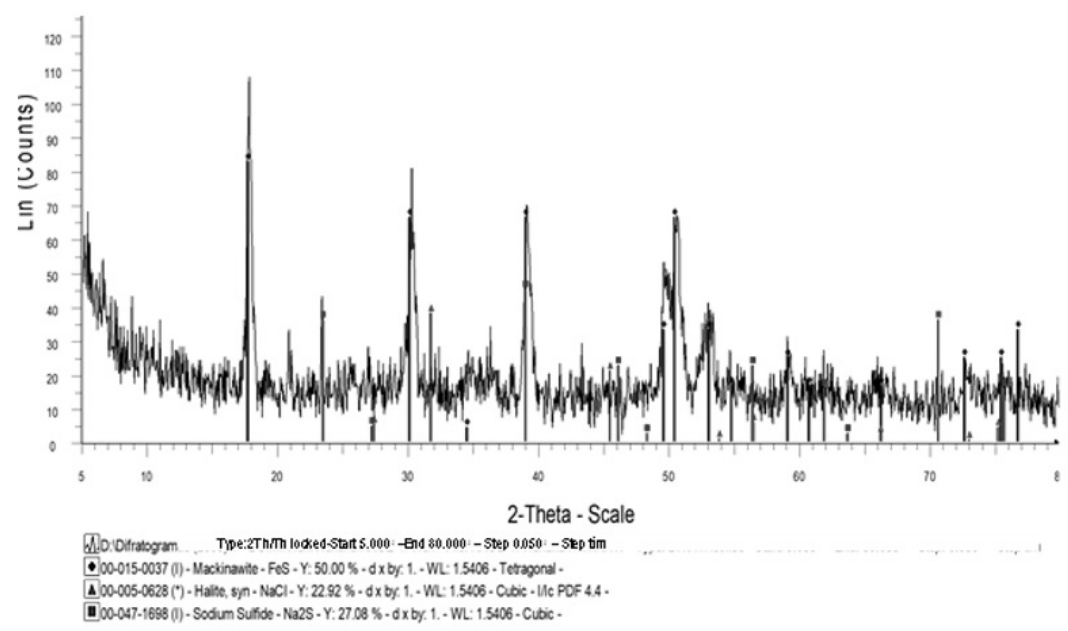

Figure 10. XRD spectrum of the corrosion product film of the welded joint that was tested in in solution 2 with $\mathrm{pH}=3.0$

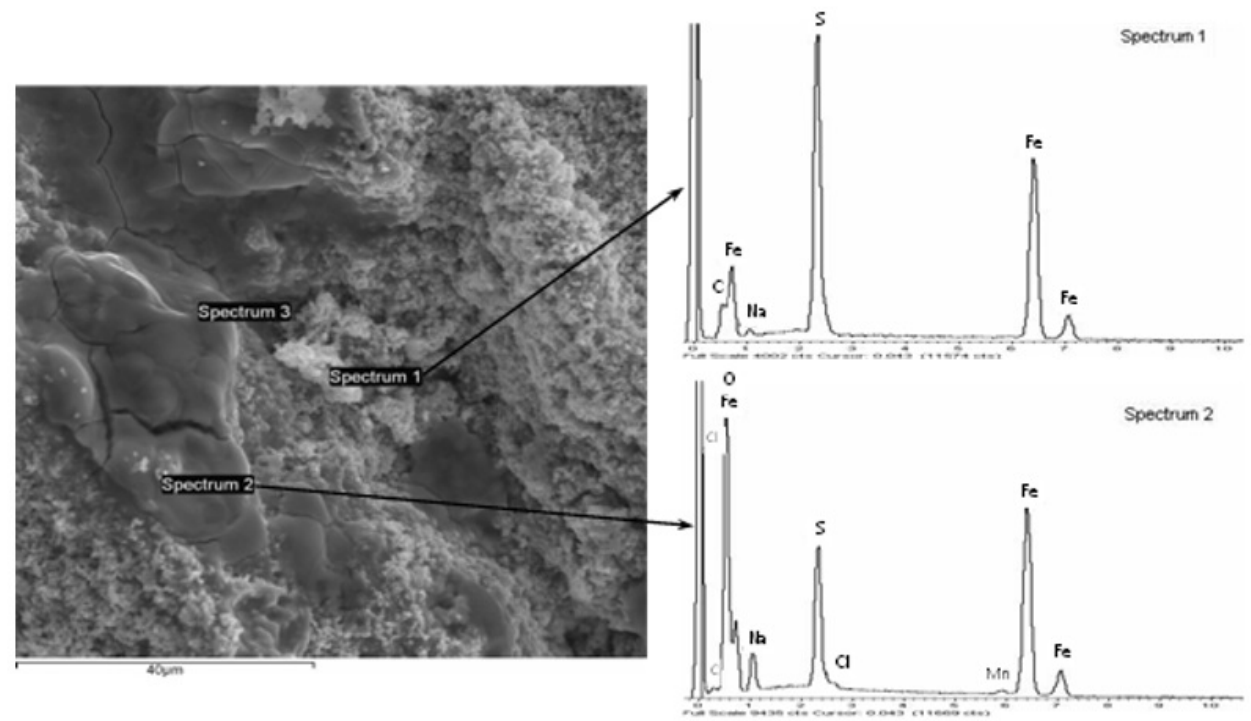

Figure 11. SEM and EDS characterization of the corrosion product film of the welded joint that was tested in solution $1 \mathrm{with} \mathrm{pH}=3.0$.

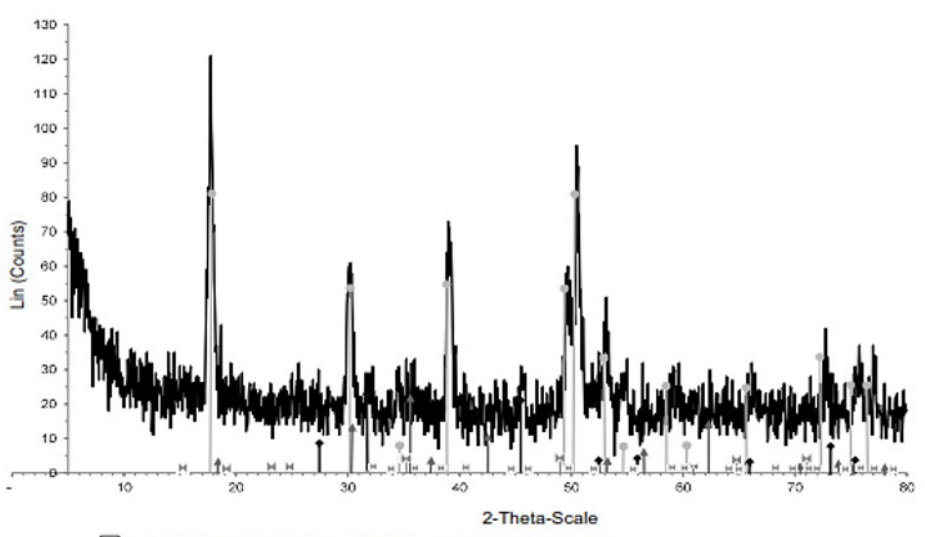

MD:11 - Ditratogram RAW - Flle: 24 RAW - Type: 2 ThUTh locked - 1

00-015-0037 (1) - Mackinawte - FeS - Y: $12.50 \%$ - d x by: 1. - WL: 1.5400 - 0 - I/IC PDF 1, - S-0 $79.2 \%$

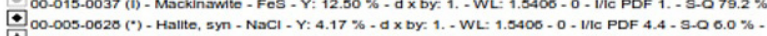

$\left.\Delta 00-019-0029()^{\circ}\right)$ - Magnette, syn - FeFe2O4 - Y: $4.17 \%$ - d x by: 1 . - WL: 1.5400 - o - I/C PDF 4.9 - S.

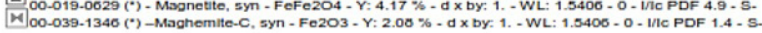

Figure 12. XRD spectrum of the corrosion product film of the welded joint that was tested in solution 1 with $\mathrm{pH}=3.0$. 
The corrosion films that formed for solution 1 exhibit a more regular and compact morphology, which contributes to the formation of protective layers and thus decreases the corrosion rate.

Figure 13 shows the characteristic curves of LPR measured at different environments with additions of sodium thiosulfate $\left(\mathrm{Na}_{2} \mathrm{~S}_{2} \mathrm{O}_{3}\right)$ for both base metal and welded joint. Comparing the linear polarization resistance curves for the different environments, the curve slope increases with increasing sodium thiosulphate concentration. As RPL parameter is indirectly proportional to the corrosion rate, there is an indication of a higher corrosion rate for environments with higher $\mathrm{H}_{2} \mathrm{~S}$ concentration.

At the anodic polarization of Tafel curves (Figure 14), which represents the anodic reaction of the corrosion process, active dissolution was observed. The cathodic curves behaviour in the brine is characterised by a smoothed limiting diffusion current density, indicating a process of reducing a compound dominant, this process being dependent on the potential. For our case, it indicates starting the process reduction of $\mathrm{H}^{+}$ion.

For the solutions containing sodium thiosulphate, the cathodic curves show the current limit more marked and this behaviour can be attributed to the process of formation of $\mathrm{H}_{2} \mathrm{~S}$ in the system and the start of the $\mathrm{H}^{+}$ion reduction.
Similar results were obtained by Lucio-Garcia et al. ${ }^{24}$, who studied the $\mathrm{H}_{2} \mathrm{~S}$ corrosion resistance of a microalloyed steel with three different heat treatments and microstructures. The addition of $\mathrm{Na}_{2} \mathrm{~S}_{2} \mathrm{O}_{3}$ and generation of $\mathrm{H}_{2} \mathrm{~S}$ in the system is reflected in all the curves obtained for solutions 1 and 2, in each case the whole curve being moved towards higher current density values compared to those obtained for the brine solution (Figure 14).

The most representative Nyquist diagrams for the different environments studied with $\mathrm{pH}=5.0$ are shown in Figure 15. At higher frequencies, the capacitive semi-circles formed, for both base metal and welded joint in the thiosulphate solutions were similar to the capacitive arc formed for the brine, although smaller, for most tests. The semicircles obtained for the solutions containing thiosulphate showed a decrease in diameter, indicating that there is a decrease in the polarisation resistance ( $\mathrm{Rp}$ ) and, therefore, an increase in the corrosion rate for these environments, as indicated previously by the LPR tests.

EIS is also used to investigate corrosion mechanisms ${ }^{26-29}$. In this work, the Nyquist plots obtained showed one capacitive loop at high frequency and one inductive loop at lower frequency values. This corresponds to a process of charge transfer for high frequencies and followed by a diffusion
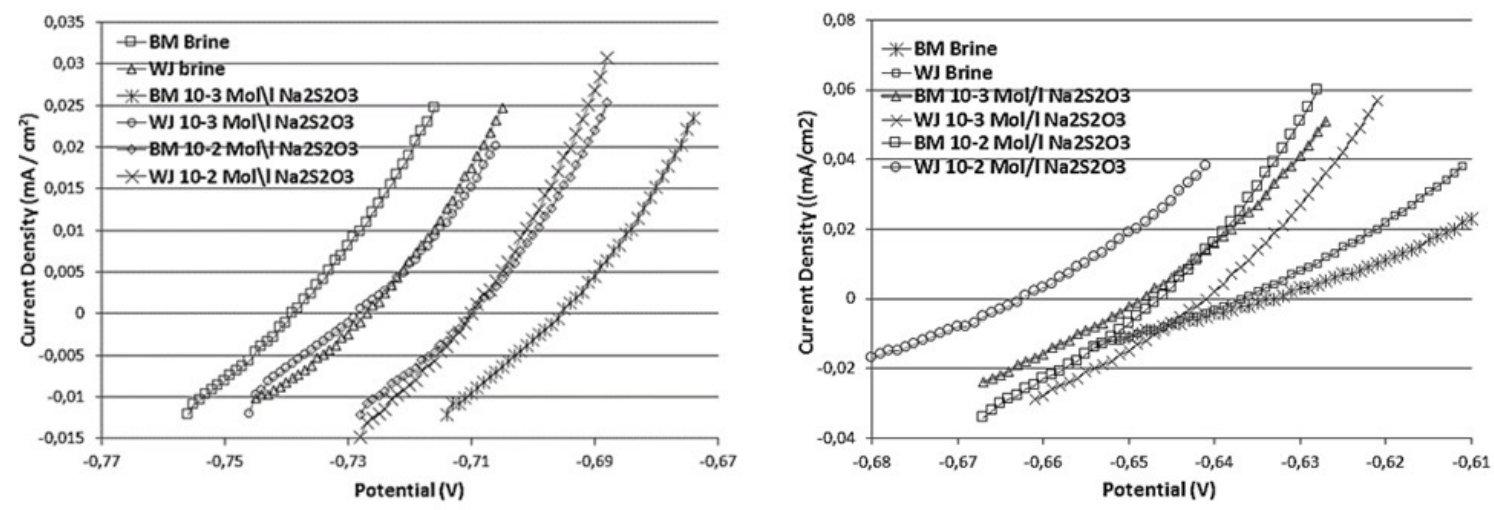

Figure 13. Characteristic LPR Curves of $\mathrm{BM}$ and $\mathrm{WJ}$ in different environments with: a) $\mathrm{pH}=5.0$ and b) $\mathrm{pH}=3.0$, respectively.
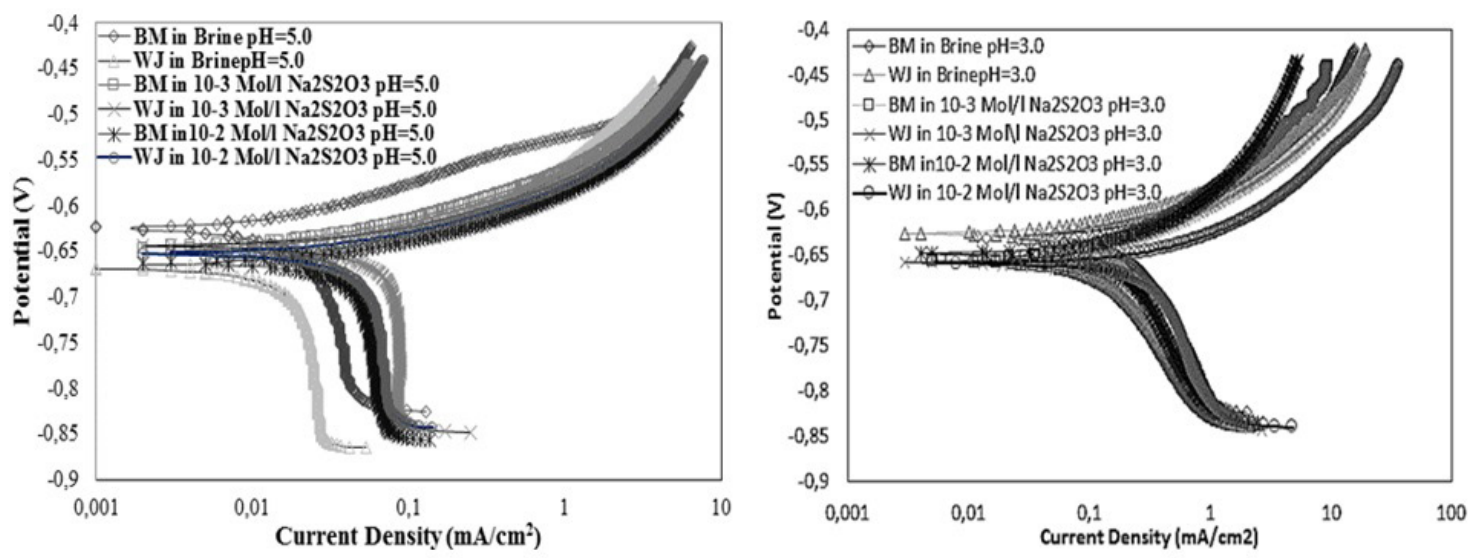

Figure 14. Characteristic Tafel Curve for the base metal and welded joint in different environments with: a) $\mathrm{pH}=5.0 \mathrm{and} \mathrm{b}$ ) $\mathrm{pH}=3.0$, respectively. 


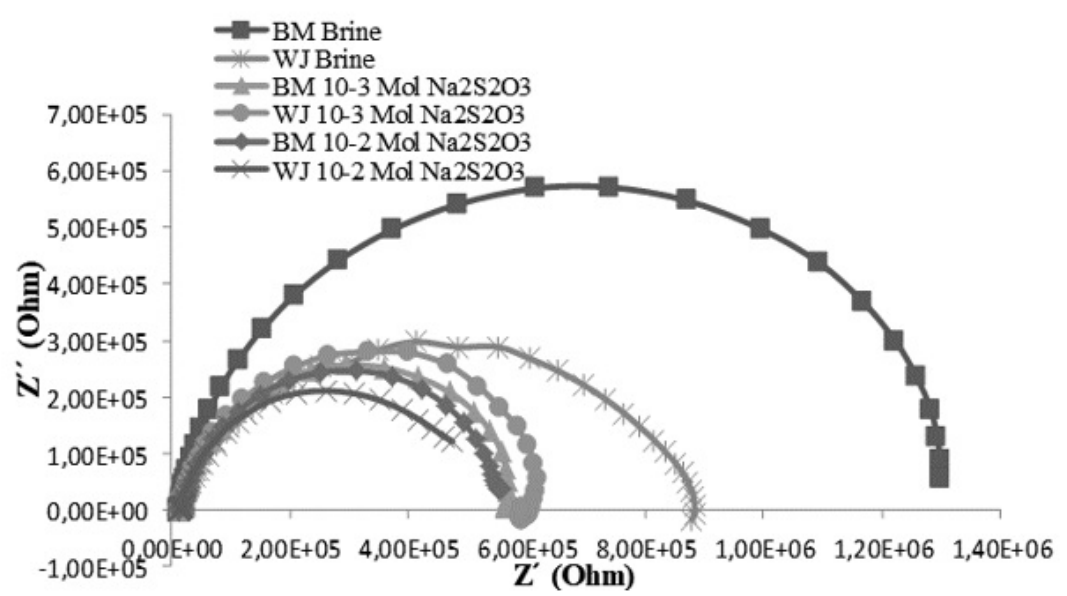

Figure 15. Characteristic Nyquist diagrams in different environments.

controlled process for lower frequencies (adsorption and dissolution of species or a nucleation stage of the scale formation process) $)^{29}$.

At lower frequencies, the Nyquist diagrams for the welded joint showed the formation of an inductive arc, this may be related to the dissolution of the iron sulfide film. However, Ma et al. ${ }^{1}$ attributed the formation of the inductive arc to the non-formation of a protective film, which disappears with the increase in immersion time, that is, this arc disappears as the sulfide film is generated on the metal surface.

Similar spectra were obtained by Choi et al. ${ }^{26}$, who investigated the mechanism of iron sulphide scale formation in $\mathrm{CO}_{2} / \mathrm{H}_{2} \mathrm{~S}$ environments and evaluated the effect of added $\mathrm{H}_{2} \mathrm{~S}$ on $\mathrm{CO}_{2}$ corrosion of carbon steel in acidic solutions. When 100ppm $\mathrm{H}_{2} \mathrm{~S}$ was added into the $\mathrm{CO}_{2}$ environment, an increase of the Rp obtained from LPR and the diameter of semicircles from EIS was observed, causing an immediate decrease in the corrosion rate. They attributed this phenomenon to the formation of a protective iron sulphide film on the steel surface. On the other hand, when $\mathrm{H}_{2} \mathrm{~S}$ was completely removed from the $\mathrm{CO}_{2}$ environment, the Rp obtained from LPR and the diameter of semicircles from EIS decreased, and the corrosion rate returned to its previous levels. They suggested that this phenomenon was due to the dissolution of the iron sulphide.

The $\mathrm{H}_{2} \mathrm{~S}$ corrosion process tends to form iron sulphide $\left(\mathrm{Fe}_{\mathrm{x}} \mathrm{S}_{\mathrm{y}}\right)$ films and, although this film can facilitate hydrogen permeation, it can also act as a physical barrier between the metal and the medium, reducing corrosion rate ${ }^{26}$. These films can vary widely in composition and stoichiometry, therefore the protective effect is dependent on the conditions of the environment in which they are formed $\mathrm{pH}$, concentration of sulphates, presence of chlorides, time of formation, liquid or gas phase and microstructure of the substrate) $)^{2,4,6,7,11,17,24,26}$. In the present case, for both techniques used RPL and EIS, an increase of the corrosion rate was observed, indicating that the film formed was not protective.

The average values for corrosion rates calculated by the two techniques used (EIS and LPR) are in good agreement, and are shown in the Table 3. The corrosion rate values increase with increasing concentration of $\mathrm{H}_{2} \mathrm{~S}$ generated by the thiosulphate. The welded joint showed higher corrosion rate in comparison with those presented by the base metal, for all conditions studied.

Comparing the results obtained for weight loss and electrochemical tests, it can be seen that the samples' immersion time is determinant in the process of layer formation and in its protective characteristics. The electrochemical tests with 24 hours' duration did not produce protective layers for all different conditions tested. On the other hand, for the weight loss tests for the samples immersed for 30 days, there was formation of protective layers for solution 1 $\left(10^{-2} \mathrm{~mol} / \mathrm{L} \mathrm{Na}_{2} \mathrm{~S}_{2} \mathrm{O}_{3}\right)$ for both $\mathrm{pH}$ tested.

Table 3. Average corrosion rates values obtained by loss weight tests, LPR and EIS techniques.

\begin{tabular}{|c|c|c|c|c|c|c|c|c|c|c|}
\hline Environment & Material & $\begin{array}{l}\text { RP DC } \\
(\Omega . \mathrm{cm} 2)\end{array}$ & $\begin{array}{l}\text { RP AC } \\
(\Omega . \mathrm{cm} 2)\end{array}$ & $\begin{array}{c}\text { C. } \\
\text { Tafel B } \\
(\mathrm{V} / \mathrm{dec})\end{array}$ & $\begin{array}{c}\text { ba } \\
(\mathrm{V} / \mathrm{dec})\end{array}$ & $\begin{array}{c}\mathrm{bc} \\
(\mathrm{V} / \mathrm{dec})\end{array}$ & $\begin{array}{l}\text { Icorr DC } \\
(\mu \mathrm{A} / \mathrm{cm} 2)\end{array}$ & $\begin{array}{l}\text { Icorr AC } \\
(\mu \mathrm{A} / \mathrm{cm} 2)\end{array}$ & $\begin{array}{l}\text { Vcorr DC } \\
(\mathrm{mm} / \mathrm{y})\end{array}$ & $\begin{array}{c}\text { Vcorr AC } \\
(\mathrm{mm} / \mathrm{y})\end{array}$ \\
\hline \multirow{2}{*}{$\begin{array}{c}\text { Brine } 5 \% \text { wt } \\
\mathrm{NaCl}\end{array}$} & $\mathrm{BM}$ & 888,96 & 933.57 & 0.022 & 0.06 & 0.381 & 25,32 & 25.32 & 0.297 & 0.282 \\
\hline & WJ & 596.98 & 586.04 & 0.019 & 0.051 & 0.368 & 32.58 & 32.26 & 0.382 & 0.391 \\
\hline \multirow{2}{*}{$\begin{array}{c}\text { Solution } 1 \\
10^{-3} \mathrm{~mol} / \mathrm{L} \mathrm{de} \\
\mathrm{Na}_{2} \mathrm{~S}_{2} \mathrm{O}_{3}\end{array}$} & $\mathrm{BM}$ & 492.89 & 432.84 & 0.018 & 0.05 & 0.269 & 36.93 & 42.31 & 0.434 & 0.502 \\
\hline & WJ & 471.05 & 410.58 & 0.019 & 0.054 & 0.279 & 41.49 & 47.83 & 0.487 & 0.563 \\
\hline \multirow{2}{*}{$\begin{array}{c}\text { Solution } 2 \\
10^{-2} \mathrm{~mol} / \mathrm{L} \text { de } \\
\mathrm{Na}_{2} \mathrm{~S}_{2} \mathrm{O}_{3}\end{array}$} & $\mathrm{BM}$ & 392.26 & 343.99 & 0.017 & 0.046 & 0.249 & 42.99 & 49.01 & 0.505 & 0.581 \\
\hline & WJ & 392.36 & 341.84 & 0.018 & 0.048 & 0.312 & 46.45 & 52.82 & 0.545 & 0.620 \\
\hline
\end{tabular}




\section{Conclusions}

The results obtained by the two techniques used (loss weight and electrochemical test) showed an increase of the corrosion rate values, with decreasing $\mathrm{pH}$ and increasing concentration of $\mathrm{H}_{2} \mathrm{~S}$ generated by the thiosulphate. For the lowest $\mathrm{H}_{2} \mathrm{~S}$ concentrations and long test times, the corrosion process was inhibited, causing a significant decrease in the corrosion rate. This effect was associated with the formation of a partially protective film formed on the samples' surfaces in solutions with low $\mathrm{H}_{2} \mathrm{~S}$ concentration.

The solution 2, with the highest concentration of thiosulfate $\left(10^{-2} \mathrm{~mol} / \mathrm{L} \mathrm{Na}_{2} \mathrm{~S}_{2} \mathrm{O}_{3}\right)$, showed the highest corrosion rate, and the welded joint showed higher corrosion rate in comparison with those presented by the base metal, for almost all conditions studied. In most cases, the heat affected zone (HAZ) showed a severe localised corrosion attack which was attributed to the microstructural characteristics of this region.

\section{Acknowledgments}

The authors wish to acknowledge the financial support of CAPES, FAPERJ and PUC-Rio.

\section{References}

1. Ma H, Cheng X, Li G, Chen S, Quan Z, Zhao S, et al. The influence of hydrogen sulphide on corrosion of iron under different conditions. Corros Sci. 2000;42:1669-83.

2. Tang J, Shao Y, Guo J, Zhang T, Meng G, Wang F. The effect of $\mathrm{H}_{2} \mathrm{~S}$ concentrations behavior of carbon steel at $90^{\circ} \mathrm{C}$. Corros Sci. 2010;52:2050-8.

3. Carneiro RA, Ratnapuli RC, Lins VFC. The influence of chemical composition and microstructure of API linepipe steels on hydrogen induced cracking and sulphide stress corrosion cracking. Mater Sci Eng A. 2003;357:104-10.

4. Park GT, Koh SU, Jung HG, Kim KY. Effect of microstructure on the hydrogen trapping efficiency and hydrogen induced cracking of line pipe steel. Corros Sci. 2008;50:1865-71.

5. Inohara Y, Ishikawa N, Endo S. Recent development in high strength linepipe for sour environment. In: Proceedings of the 13th International Offshore and Polar Engineering Conference; 2003 May 25-20; Honolulu, Hawaii. Proceedings. Cupertino: International Society of Offshore and Polar Engineers (ISOPE); 2003, p. 60-66.

6. Koh SU, Kim JS, Yang BY, Kim KY. Effect of line pipe steel microstructure on susceptibility to sulphide stress cracking. Corrosion. 2004;60:244.

7. Ballesteros AF, Ponciano JAC, Bott IS. Susceptibility of pipeline girth welds to hydrogen embrittlement and sulphide stress cracking. Materials and Corrosion. 2012;63:9999. http:// dx.doi.org/10.1002/maco.201206574.

8. Bott IS, Souza LFG, Teixeira JCG, Rios PR. High strength HTP steel development for pipelines: a Brazilian perspective. Metal Mat Trans A. 2005;36A:443-54.

9. Ren C, Liu D, Bai Z, Li T. Corrosion behavior of oil tube steel in stimulant solution with hydrogen sulphide and carbon dioxide. Mater Chem Phys. 2005;93:305-9.

10. Lu BT, Luo JL. Relationship between yield strength and near neutral $\mathrm{pH}$ stress corrosion cracking resistance of pipeline steels - An effect of microstructure. Corros Sci. 2006;62(2):129-40.
11. Albarran JL, Martinez L, Lopez HF. Effect of heat treatment on the stress corrosion resistance of the microalloyed pipelines steel. Corros Sci. 1999;41:1037-49.

12. Bulger J, Lou J. Effect of microstructure on near-neutral $\mathrm{pH}$ SCC. In: International Pipeline Conference; 2000 Oct 1-5; Calgary. Proceedings. New York: ASME; 2000.

13. Leyer J, Sutter P, Marchebis H, Bosch C, Kulgemeyer A, Orlans JBJ. SSC resistance of a $125 \mathrm{Ksi}$ steel grade in slightly sour environments. NACE - International Corrosion Conference Series. 2005;2005:05088.

14. Natividad C, Salazar M, Garcia R, Gonzalez-Rodriguez JG, Perez R. Sulphide stress cracking behavior of weldments produced by indirect electric arc welding. Corros Eng Sci Technol. 2006;41(1):91-5.

15. Natividad C, Salazar M, Contreras A, Albiter A, Pérez R, GonzalezRodriguez JG. Sulphide stress cracking susceptibility of X-60 and X-65 steel weldments. Corrosion. 2006;62(5):375-82.

16. Beavers JA, Jonson JT, Sutherby RL. Materials factors influencing the initiation of near-neutral $\mathrm{pH}$ SCC on underground pipelines. In: International Pipeline Conference; 2000 Oct 1-5; Calgary. Proceedings. New York: ASME; 2000. p. 979-988.

17. Omweg GM, Frankel GS, Bruce WA, Ramirez JE, Koch G. Effect of welding parameters and $\mathrm{H} 2 \mathrm{~S}$ partial pressure on the susceptibility of welded HSLA steel to sulphide stress cracking. Welding Research. 2003;82(6):136-143.

18. Sardico JB, Pitts RE. Corrosion of iron in an $\mathrm{H} 2 \mathrm{~S}-\mathrm{CO} 2-\mathrm{H} 2 \mathrm{O}$ system composition and protectiveness of the sulfide film as a function off $\mathrm{pH}$. Corrosion. 1965;21(11):350-4.

19. ASTM: American Society for Testing and Materials. ASTM G1 - 03 (Reapproved 2011): standard practice for preparing, cleaning, and evaluating corrosion test specimens. West Conshohocken: ASTM; 2012.

20. ASTM: American Society for Testing and Materials. ASTM G5997: Standard practice for conducting potentiodynamic polarization resistance measurements. West Conshohocken: ASTM; 2003.

21. Kane RD. Roles of $\mathrm{H}_{2} \mathrm{~S}$ in behaviour of engineering alloys. International Metals Reviews. 1985;30(6):291-301.

22. ASTM: American Society for Testing and Materials. ASTM D2688 - 11: standard test method for corrosivity of water in the absence of heat transfer (weight loss method). West Conshohocken: ASTM; 2011.

23. Zhou C, Zheng S, Chen C, Lu G. The effect of the partial pressure of $\mathrm{H}_{2} \mathrm{~S}$ on the permeation of hydrogen in the low carbon pipelines steel. Corros Sci. 2013;67:184-92.

24. Lucio-Garcia MA, Gonzalez-Rodriguez JG, Casales M, Martinez L, Chacon-Nava JG, Neri-Flores MA, et al. Effect of heart treatment on $\mathrm{H}_{2} \mathrm{~S}$ corrosion of micro-alloyed C-Mn Steel. Corros Sci. 2009;51:2380-6.

25. Ballesteros AF, Ponciano JAC, Bott IS. Corrosion evaluation of SAW Welded API 5L X-80 joints in H2S-containing solution. Mater Res. 2015; 18:417-26.

26. Choi YS, Nesic S, Ling S. Effect of $\mathrm{H}_{2} \mathrm{~S}$ on the $\mathrm{CO}_{2}$ corrosion of carbon steel in acidic solutions. Electrochim Acta. 2011;56:1752-60.

27. Fragiel B, Serna S, Perez R. Electrochemical study of two microalloyed pipeline steels in $\mathrm{H} 2 \mathrm{~S}$ environments. Int J Hydrogen Energy. 2005;30:1303-9.

28. Arzola S, Mendoza J, Duran R, Genesca J. Electrochemical behavior of API X70 steel in hydrogen sulfide-containing solutions. Corrosion. 2006;62:433-42.

29. Maddala J, Sambath K, Kumar V, Ramanahan S. Identification of reaction mechanism for anodic dissolution of metals using Electrochemical Impedance Spectroscopy. J Electroanal Chem. 2010;638:183-8. 